\title{
FREELANCERS PERCEPTION TOWARDS REMITTANCE POLICIES AND ITS CONSEQUENCES ON THE ECONOMY OF PAKISTAN
}

\author{
Hafiz Muhammad \\ Farrukh Tahir ${ }^{1+}$ \\ Sohaib Uz Zaman ${ }^{2}$
}

\author{
${ }^{1,2}$ Karachi University Business School, University of Karachi, Pakistan. \\ 'Email:Farrukh411@gmail.com Tel:00923313499736 \\ sEmail:Sohaiburraman@uok.edu.pk.Tel:00923312641245
}

(i) Check for updates

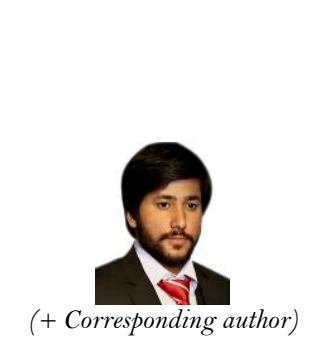

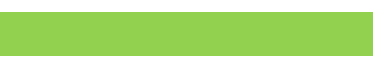

Article History

Received: 4 January 2021 Revised: 20 January 2021 Accepted: 2 February 2021 Published: 16 February 2021

\section{Keywords}

Remittances

Freelancers perception

Economy of the county

growth

Remittance policies

I.T export services.

\section{ABSTRACT}

As the last century is witnessed that the thinking of employees and corporates have changed drastically due to the evolution of occupation and technology enhancement. Freelancers have changed a mindset of individuals to take initiative for their own business instead to work as a slave for a corporate. Due to the influencing thoughts of an individual, it directly impacts on country's economy. Now a huge portion of economic growth depends on remittances (inward) against I.T (information technology) services, consultancy, and export of software and I.T packages. So, therefore a lot of dependency on economic growth be contingent on freelancer perception of remittance policies. So, the survey was conducted among freelancers and respondents' responses were tested through SmartPLS. Right now, most of the developing countries encourage youth to I.T because it has several positive consequences either directly (Foreign Direct Investment, Balance of Payment and Reserves) or indirectly (Employment and Growth Opportunities of SMC).

Contribution/ Originality: This study is one of the very few studies that have investigated in the field of freelancing and proves that freelancers are contributing to the growth of the economy (unintentionally) but on the other hand, government policies are not user friendly because most of the times I.T specialists faced difficulties while realizing funds to their accounts (against export I.T services).

\section{INTRODUCTION}

The media and networking industry has produced a high proportion of freelancers and made several small businesses and companies. In surrounding and within the economy workers in the field have created opportunities for those who have skills. The supreme freelancers who have abilities directly pertain to programming, development, media designing, web development, and multimedia (Kozierok, 2011) Freelancers are totally committed to the job because of deadlines and commitments with clients. It has further seen that most of the field experts are youngsters and singles whose age within 30. The commitment towards the job is basically a reason of age, independent approach, and thirst for knowledge. In the long run, the approach may be supported to the whole economy through the increase of export and related services.

Another study witnessed that, in the case where a tradeoff between the flexibility in the form of employment and with employee commitment on other hand, the commitment would be decline with the growing flexibility (Kulkarni \& Ramamoorthy, 2005). Several participate pertains to the field of freelancing are participating in the 
platform of digital freelancing such as Amazon Mechanical Turk, Upwork, and Freelancer.com because these are proving opportunities with assistance and have millions of members (Pongratz, 2018) and according to the recent statistics the platform users are drastically increasing by more than 25 percent per year (Lehdonvirta, 2018). As per the research, Empirical evidence about freelancing in the field reveals that the working conditions are flexible, less pressure, and in terms of income are more attractive. With available platforms, most of the freelancers accomplished works for corporates because everyone is not specialists in every field so giants within the domain prefer to work outsourced instead to hire specialists. Tasks are no longer accomplished within companies but rather outsourced to specialists who perform at higher levels of efficiency. Within the outsourcing companies, workplaces become obsolete and a layoff of permanent employees ensues (Storey, Salaman, \& Platman, 2005). These facts seem to indicate that freelancers want a professional career as entrepreneurs that allows them to perform assignments as per their own desire. Thus, in the media industry of Pakistan, highly educated and experts are likely to provide their own design services instead to go for a job. It has two reasons, First - borders between work and life in terms of time, space, and social contacts. Second - the arrangements of work-life i.e. need of a dual job.

The professor of MIT Paul Osterman argued that, If the job of the employees provides them flexible hours, learning, and real skills with handsome wages the consequences on the economy would be positive (Godelnik, 2017). This study, it's directly pertains to the remittance consequences on the economy which route against freelancing services. In general, the increase in investment and consumption is a sign of economic development. So, the investment in the form of remittances directly supports poverty reduction, income planning, and balance of payment. The basic aim of the paper is to investigate the economic growth and foreign remittances relationship and its behavior within the economy of Pakistan. Remittances are increasing day by day and currently, Pakistan is among top countries in the world because residents of the country residing abroad for job and another inflow through digital consultancy.

\subsection{Background to the Study}

Related to this study conducted by many researchers with an approach of remittances impact the economy (Meyer \& Shera, 2017) and foreign remittances and economic growth in Pakistan. Many researchers concerning freelancers perception also conducted in past; Commitment and work-related expectations in flexible employment forms: An empirical study of German IT freelancers (Süß \& Kleiner, 2010) In search of meaningful work on digital freelancing platforms: the case of design professionals (Nemkova, Demirel, \& Baines, 2019) The needs of freelancers and the characteristics of 'gigs': (Barlage, van den Born, \& van Witteloostuijn, 2019) and Broadcasting discontentfreelancers, trade unions, and the (Saundry, Stuart, \& Antcliff, 2007). In past, researchers independently analyze the behavior and dimensions of freelancers and economic growth.

\section{GAP ANALYSIS}

This study is to analyze the impact of remittance policies on the economy with the perception of freelancers because it is important to provide a secure and independent venue to freelancers towards remittance policies. As several studies were conducted about freelancers' attitudes, behavior, and perception but with a gap in the behavior of individuals towards the economy of the country. The isolated attitude of a worker in terms of time and space seem but with the provision of the location where workers can meet, discuss, inform and exchange of ideas make individual happy (Chawathe et al., 1994; Greene \& Kirton, 2003). Pakistan’s economy is expanding using export through services and most of the service providers pertain to I.T (information technology).

To understand the meaning of work, it is necessary to understand its dependence and its context in which that work takes place (Spencer, 2017; Spencer., 2015). The research also includes the conceptual form that how the economy can be diversified by technology and can be a move towards growth. As the economy can be expanded and the nature of work is reframed through meaningful and technical work which can only be possible through creative 
freelancer experience (Kalleberg \& Dunn, 2016). So, the study is mainly conducted on freelancers to know the perception of them on remittance policies as well its consequences on the overall economy of Pakistan through primary and secondary research approach.

\section{RESEARCH OBJECTIVE}

The main objective of the research is to highlight the relationship among the perception of freelancers, remittance policies, and its consequences through practical application and analysis of data. Further, this the study aims to conduct on the basis to achieve;

Firstly, it aims to explore the relationship between the perceptions of freelancer towards the policies of remittances made by Pakistan.

Secondly, it seeks to inspect the relationship between remittances policies and its consequences.

Thirdly, it purports to examine the overall impact on the economy of the country.

\section{RESEARCH QUESTIONS}

This study poses the undermentioned questions

Q1. Does remittance policies affect freelancer's perception?

Q2. Does Freelancers perception impact the economy of the country?

Q3. Does the economy of the country effect through remittances which route/inflow against I.T services?

\section{LITERATURE REVIEW}

\subsection{Freelancers Perception and Remittance Policies}

Despite the unpredictable and unstable economy of Pakistan. It has been observed that the only growth found in the sector of I.T (information technology) which is mostly handled by freelancers. According to the presenter, a freelancer is a person who worked and performs duties by themselves. Actually, manage multiple clients by oneself. The earning is usually per-job basis, charging daily, hourly as per work. Freelancer work is usually a short-term (Freelancer Definition-Debitoor Accounting). This study is based on two sections and both have their own dimensions. The perception of an individual who is currently earning through I.T services is analyzed through primary research by the conventional approach

Questionnaire development and responses from respondents (freelancers only) and the remittances policies designed by the government of Pakistan for those also assess through a questionnaire. A questionnaire to assess the perception of freelancers adopted from the previous research which was related to alexithymia. A model was presented by Rieffe, Oosterveld, and Terwogt (2006). The EAQ (Emotion Awareness Questionnaire) the scale is based on to assess the perception and emotions of individuals. So, the selected questionnaire is the best suit for the current study. A model questionnaire related to remittances policies adopted from Hooi Lai Wan research conducted in 2007 (Wan, 2007) It has been critically observed while this research was conducted that previously no sound worked performed by any of the researchers in this area because from the year 2000 to date freelancers always ignored by society.

When the system of reputation fail, a fine seller reward the market through his premium expertise and lowquality seller leave the market which causes positive consequences and turn market into equilibrium (Abel, 1970). At this approach, right now I.T services are easily available to everyone at the doorstep otherwise the control over the same by giants and corporates. Freelancers have changed the market dynamics.

\subsection{Economy of Pakistan}

Since the day of independence (Aug 14, 1947), the economy of Pakistan depends on heavy textile, agricultural, and food production. Though recent years have seen a technological diversification and its consequences drastically 
impact the economy of the country (Source: Wikipedia, (Armstrong et al., 1971)). Most of the time Pakistan's budget faced a deficit (expenditure over income) which means to settle the same should take heavy financing to cover all these gaps. As reviewed and analyzed data taken collected from authorized sources the income side of the Pakistan economy is growing due to increase in trade against technology and freelancers performing more than expected as it has a direct impact as well indirect;

Table-1. Impact on Economy

\begin{tabular}{c|c}
\hline Direct Impact & Indirect Impact \\
\hline Balance of Payment & Employment \\
\hline Investment & Opportunities of Growth (Sole to Corporate) \\
\hline Income & - \\
\hline Reserves & - \\
\hline
\end{tabular}

\subsubsection{Direct Impact}

The direct impact through remittances can be assess through the behavior of income variation of the country whether an adequate amount of revenue has generated to meet the expenditure or would need financing to meet the deficiency. A study conducted to analyze the impact of remittances so, the balance of payment, investments, and income is directly under its ambit.

\subsubsection{Balance of Payment}

The balance of payment (BOP) is a statement of transactions covering all transactions between entities with the rest of the world over a period of defined time, such as a year. The BOP includes the current and capital accounts. Whereas the current account includes a country's net trade against goods and services, net earnings on crossborder earnings, and net transfer payments. The capital account basically consists of transactions related to financial instruments and central bank reserves. Further another variable is an ambit of BOP which is remittances. Money that is received from another country against the exchange of goods, services, or financial assets. As a practice, the sum of all the transactions should be zero (State Bank of Pakistan-Google Search, 2020; State Bank of Pakistan Balance of Payment, 2020).

\subsubsection{Investments}

Here, in this research, foreign investment is related to that particular type of investment which refers to investment in domestic companies and assets of a foreign company in domestic. It is commonly seen, large multinational companies or corporations spend a huge amount to open a branch or regional office to another country for growth that is an alien investment.

Foreign direct investment may include a long term physical investment, technology provision, or opening a plant. Whereas a foreign indirect investment consists of investment in the share capital market, commercial loans a loan to foreign companies finance by domestic institutions against interest or loan to foreign countries (State Bank of Pakistan-Google Search, 2020).

5.2.1.3. Income

As most of the avenues of government comes from individual income taxes (employees on payroll), remaining from corporates and from individuals (small businesses) and rest comes from mix sources. Here, in this research it is observed that an appreciable step of government that no tax against I.T related services (export) but government manages income through I.T Avenue (individual I.T services provider also a part to support government while manages fiscal budget) (Income, 2021). 


\subsubsection{Reserves}

Those assets are readily available to and can control by the country's authorities as it has a direct impact on the balance of payment. In another word, a currency or bonds which are ultimately controlled under the authority of the country. It increased through inwards remittance whether may send citizens of Pakistan currently residing abroad or against services and export of I.T related packages (RESERVE | Meaning in the Cambridge English Dictionary, 2020).

\subsubsection{Indirect Impact}

The indirect impact through remittances can be assess through the other sector variations i.e. employment opportunities and opportunities of growth to business sector.

\subsubsection{Employment Opportunities}

Employment opportunities directly create through provision of avenues to individuals who want to work on an independent basis on internet. There is a direct relation between self-employee and remittance policies because after completion of the assignment the individual face difficulties to realize his proceeds. Right now, the only way to clear proceeds are either to go to financial institute (bank) or Money dealer i.e. money gram, western union and others (Cox, 1972).

\subsubsection{Opportunities of Growth}

Another advantage to those who are currently working as individuals and seeking to open a registered business and wish to become a corporate giant in the field of I.T. According to the survey conducted, the overall business just crossed 3.3 billion in the year of 2018 and around 2.8 during 2016 - 2017 as per the record of Pakistan Software Export Board. Ultimately, its impact on to fall the rate of unemployment, inflation, and poverty.

\section{HYPOTHESIS DEVELOPMENT}

The basis and one of the most key challenge of every freelancer is not with the industry but how to cope with the tendency to typecast (Zuckerman, Kim, Ukanwa, \& Von Rittmann, 2003). As remittances are a new financial phenomenon and one of the main important sources of incomes based on its seize and economic impact in the world. Data from. In the light of the literature review, the considerable model has been developed based on hypothesis;

H1: There is a positive and a significant impact of freelancer perception on inward remittance policies.

H2: There is a positive and a significant impact of Inward remittance on the economy of the country.

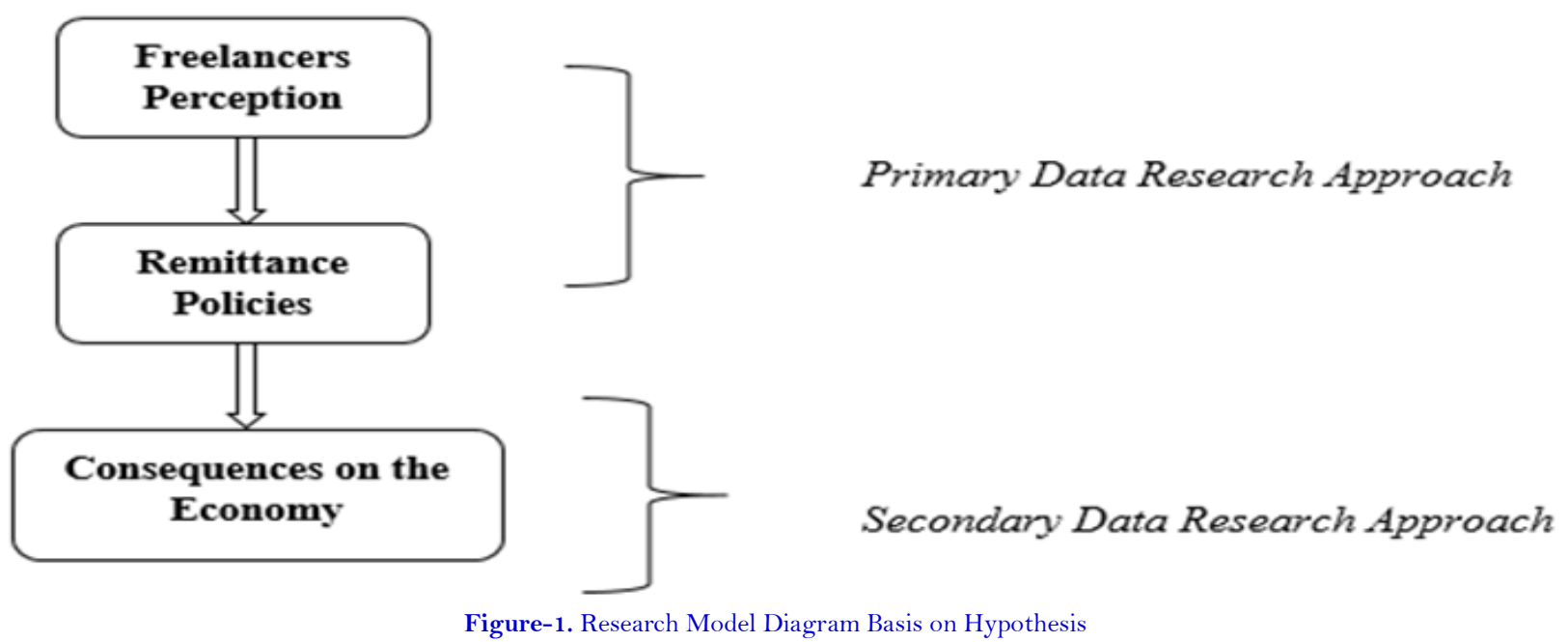

Figure-1. Research Model Diagram Basis on Hypothesis 


\section{RESEARCH METHOD}

The research has two-part, one pertains to analyze the perception of freelancers towards remittance policies which are consists of a primary or conventional approach and the second pertains to its consequences on the economy by evaluation of past data concerning remittances only. During the research survey, only those results consider which received from individual freelancers only. About 237 responses received and 204 considered for the test. The respondent filed the questionnaire through the physical ticking of the form and some of the responses were conducted on the telephone.

\subsection{Instrument}

The instrument of the current study is divided into two dimensions where first consist of two parts on primary approach and second dimension pertains to secondary approach.

In primary, first pertains to perceptions of freelancers, the questionnaire developed from the Rieffe et al model conducted in 2006 (Rieffe et al., 2006). The model has 3 Likert scale where 1 equals to not true, 2 equals to sometimes, and 3 against often true. The second part of the study pertains to responses against remittance policies from the same respondents. The questionnaire was developed and adopted from the model (Wan, 2007). The model has a 5 Likert scale where 1 equals to strongly disagree and 5 against strongly agree.

In secondary approach, the basis of that consists of analysis and be to assess the behavior of Inflation, Unemployment, reserves, and remittance flows in the economy.

\subsection{Measures}

The research was analyzed by using the statistical tool for primary data which is partial least square (Bido, Silva, \& Ringle, 2014) for windows version 03. For analysis of data the validity and reliability test was applied. The outcome is taken from the package using bootstrapping and algorithm. Further for secondary data, a conventional approach used which is based on bars and diagrams to reflect the data.

\subsection{Demographic Analysis}

Table-2. Descriptive Analysis Table

\begin{tabular}{l|c|c}
\hline Age & Frequency & Analysis \\
\hline Less Than 25 & 37 & $18.14 \%$ \\
\hline Between 25 to 30 & 107 & $52.45 \%$ \\
\hline Between 30 to 35 & 53 & $25.98 \%$ \\
\hline More than 35 & 7 & $3.43 \%$ \\
\hline Gender & Frequency & Analysis \\
\hline Male & 174 & $85.29 \%$ \\
\hline Female & 30 & $14.71 \%$ \\
\hline Education & Frequency & Analysis \\
\hline Intermediate & 47 & $23.04 \%$ \\
\hline Bachelors & 131 & $64.22 \%$ \\
\hline Certificate & 26 & $12.75 \%$ \\
\hline Working Experience & Frequency & Analysis \\
\hline Less Than 1 Year & 21 & $10.29 \%$ \\
\hline More Than 1 Year & 37 & $18.14 \%$ \\
\hline Between 2 to 4 Year & 93 & $45.59 \%$ \\
\hline More than 5 Year & 53 & $25.98 \%$ \\
\hline
\end{tabular}

In the given Table 2 , the sample consist of 204 respondents and pertains to I.T profiles only and providing freelancing services. The criteria selected especially because research is based to assess the perception of freelancers and their views of remittance policies of Pakistan. Most of the respondent's age is more than 25 which means youth 
is interested ted to pursue a career in the field of it further, most of them are male, and have bachelor's degree and more than 02 years of experience.

Table-3. Outcome result table fro SmartPLS

\begin{tabular}{|c|c|c|c|c|c|c|}
\hline Variables & Questions & $\begin{array}{l}\text { Original } \\
\text { Sample } \\
(\mathbf{O})\end{array}$ & $\begin{array}{l}\text { Sample } \\
\text { Mean } \\
(\mathrm{M})\end{array}$ & $\begin{array}{l}\text { Standard } \\
\text { Deviation } \\
(\text { STDEV) }\end{array}$ & $\begin{array}{l}\text { T Statistics } \\
(|\mathbf{O} / \mathrm{STDEV}|)\end{array}$ & $\begin{array}{c}\mathbf{P} \\
\text { Values }\end{array}$ \\
\hline \multirow{15}{*}{ 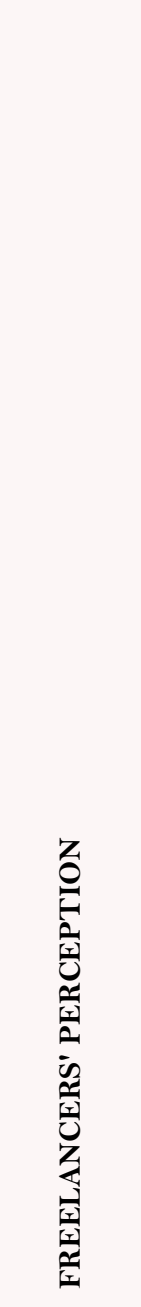 } & $\begin{array}{l}\text { I am often confused or puzzled about } \\
\text { what I am feeling because of my job } \\
\text { nature }\end{array}$ & 0.531 & 0.520 & 0.073 & 7.234 & 0.000 \\
\hline & $\begin{array}{l}\text { I never know exactly what kind of } \\
\text { feeling I am having while doing my job }\end{array}$ & 0.707 & 0.702 & 0.039 & 18.024 & 0.000 \\
\hline & $\begin{array}{l}\text { Sometimes, I feel upset and I have no } \\
\text { idea why because of my job }\end{array}$ & 0.512 & 0.493 & 0.093 & 5.509 & 0.000 \\
\hline & $\begin{array}{l}\text { I don't know when something will } \\
\text { upset me or not }\end{array}$ & 0.620 & 0.617 & 0.053 & 11.766 & 0.000 \\
\hline & $\begin{array}{l}\text { I find it difficult to explain to a friend } \\
\text { how I feel while doing my work }\end{array}$ & 0.586 & 0.573 & 0.075 & 7.804 & 0.000 \\
\hline & $\begin{array}{l}\text { I find it hard to talk to anyone about } \\
\text { how I feel about my job }\end{array}$ & 0.582 & 0.589 & 0.055 & 10.508 & 0.000 \\
\hline & $\begin{array}{l}\text { I can easily explain to a friend how I } \\
\text { feel inside }\end{array}$ & 0.568 & 0.560 & 0.066 & 8.553 & 0.000 \\
\hline & $\begin{array}{l}\text { When I am upset about something, I } \\
\text { often keep it to myself }\end{array}$ & 0.501 & 0.490 & 0.100 & 4.988 & 0.000 \\
\hline & When I am upset, I try not to show it & 0.568 & 0.560 & 0.079 & 7.200 & 0.000 \\
\hline & $\begin{array}{l}\text { When I am feeling bad, it is no one } \\
\text { else's business }\end{array}$ & 0.424 & 0.404 & 0.109 & 3.887 & 0.000 \\
\hline & $\begin{array}{l}\text { don't want to know how my friends are } \\
\text { feeling about my job nature }\end{array}$ & 0.495 & 0.477 & 0.094 & 5.281 & 0.000 \\
\hline & $\begin{array}{l}\text { I don't care about how my friends are } \\
\text { feeling inside because of my nature of } \\
\text { job }\end{array}$ & 0.418 & 0.400 & 0.099 & 4.212 & 0.000 \\
\hline & $\begin{array}{l}\text { It is important to understand how I am } \\
\text { feeling }\end{array}$ & 0.629 & 0.629 & 0.057 & 10.946 & 0.000 \\
\hline & $\begin{array}{l}\text { I always want to know why I feel bad } \\
\text { about something }\end{array}$ & 0.647 & 0.642 & 0.051 & 12.643 & 0.000 \\
\hline & $\begin{array}{l}\text { I always know how my friends are } \\
\text { feeling about my work }\end{array}$ & 0.606 & 0.607 & 0.059 & 10.319 & 0.000 \\
\hline \multirow{7}{*}{ 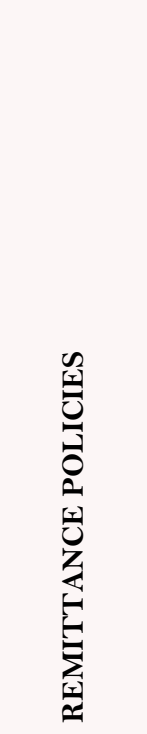 } & $\begin{array}{l}\text { The government does a good job of } \\
\text { providing opportunities for } \\
\text { development and growth for freelancers }\end{array}$ & 0.796 & 0.796 & 0.032 & 25.155 & 0.000 \\
\hline & $\begin{array}{l}\text { People have equal access to job-related } \\
\text { training opportunities }\end{array}$ & 0.804 & 0.804 & 0.032 & 24.856 & 0.000 \\
\hline & $\begin{array}{l}\text { I have the opportunity to work with } \\
\text { up-to-date technologies }\end{array}$ & 0.760 & 0.760 & 0.040 & 19.200 & 0.000 \\
\hline & $\begin{array}{l}\text { I have the opportunity to learn skills } \\
\text { that will improve my chances for } \\
\text { growth }\end{array}$ & 0.771 & 0.770 & 0.037 & 20.844 & 0.000 \\
\hline & $\begin{array}{l}\text { There are government concerns' to } \\
\text { whom I can go for help when I have } \\
\text { payment/remittance related problems }\end{array}$ & 0.794 & 0.793 & 0.039 & 20.462 & 0.000 \\
\hline & $\begin{array}{l}\text { Government provides me with the } \\
\text { appropriate amount } \\
\text { available when I need }\end{array}$ & 0.743 & 0.740 & 0.052 & 14.236 & 0.000 \\
\hline & $\begin{array}{l}\text { Government encourages me to grow } \\
\text { more through relaxation in policies. }\end{array}$ & 0.750 & 0.749 & 0.038 & 19.826 & 0.000 \\
\hline
\end{tabular}




\subsection{Descriptive Analysis}

The outcome from SmartPLS against testing of outer loadings.

It can be observed in the above table 3 that there is a significant impact of freelancers' perception towards remittance policies. As values obtained from the results falling under the acceptance level and outcome of all $P$ values values is equitant to 0.000 which means IV (Independent variable) has a direct and positive impact on DV (Dependent variable). As per the Likert scale of $3(I V)$ and on the Likert scale of $5(D V)$. The results are at an acceptable level.

\section{DATA ANALYSIS}

\subsection{Tests for Data Analysis}

To check the hypothesis, the related and relevant tests have been applied and run on Smart PLS. The confirmatory factor analysis runs to test the hypothesis. Cronbach's alpha was used to check the reliability and validity of the data. The outcome from skewness and kurtosis of all tested variables are below the threshold i.e. 3.0 and 10.0. The sound analysis of the study found and had not an issue of normality. An average outcome from Cronbach's alpha found is 0.868 out of 1.00 which is at the level of acceptance (George \& Mallery, 2003). The test of Kaiser-Mayer-Olkin applied and have adequate measure of sampling outcome further, the test for discriminant validity (Fornell-Larcker Criterion) run to check the non-over-lapping factor.

Table-4. Reliability and Validity.

\begin{tabular}{c|c|c|c|c}
\hline & Cronbach's Alpha & rho_A & Composite Reliability & $\begin{array}{c}\text { Average Variance } \\
\text { Extracted (AVE) }\end{array}$ \\
\hline Freelancer Perception & 0.848 & 0.856 & 0.873 & 0.319 \\
\hline Remittance Policies & 0.889 & 0.891 & 0.913 & 0.600 \\
\hline
\end{tabular}

Table-5. LV Descriptives.

\begin{tabular}{|c|c|c|c|}
\hline & Excess Kurtosis & Skewness & Number of Observations Used \\
\hline Freelancer Perception & 3.928 & -1.537 & 204 \\
\hline Remittance Policies & 0.627 & -0.822 & 204 \\
\hline
\end{tabular}

Table-6. Discriminant validity fornell-larcker criterion.

\begin{tabular}{c|c|c}
\hline & Freelancer Perception & Remittance Policies \\
\hline Freelancer Perception & 0.565 & \\
\hline Remittance Policies & 0.534 & 0.774 \\
\hline
\end{tabular}

\subsection{Model Fit Summary}

Model fit summary checked based on tests run on SmartPLS. A fit model shows that the proposed data and model is reliable. As for quality criteria, the tests consist of; Chi-square, SRMR (Standardized Root Mean Square Residual), d_ULS, d_G. The test for either data is well for theory is NFI. The test for VIF (Collinearity Statistics) and HTMT (Heterotrait-Monotrait Ratio) run for quality criteria.

Table-7. Fit Summary.

\begin{tabular}{l|c|c}
\hline & Saturated Model & Estimated Model \\
\hline SRMR & 0.081 & 0.081 \\
\hline d_ULS & 1.646 & 1.646 \\
\hline d_G & 0.479 & 0.479 \\
\hline Chi-Square & 529.766 & 529.766 \\
\hline NFI & 0.707 & 0.707 \\
\hline
\end{tabular}




\begin{tabular}{l|c|c}
\hline & Freelancer Perception & Remittance Policies \\
\hline Freelancer Perception & & \\
\hline Remittance Policies & 0.583 & \\
\hline
\end{tabular}

\subsubsection{Hypothesis Model Diagram}

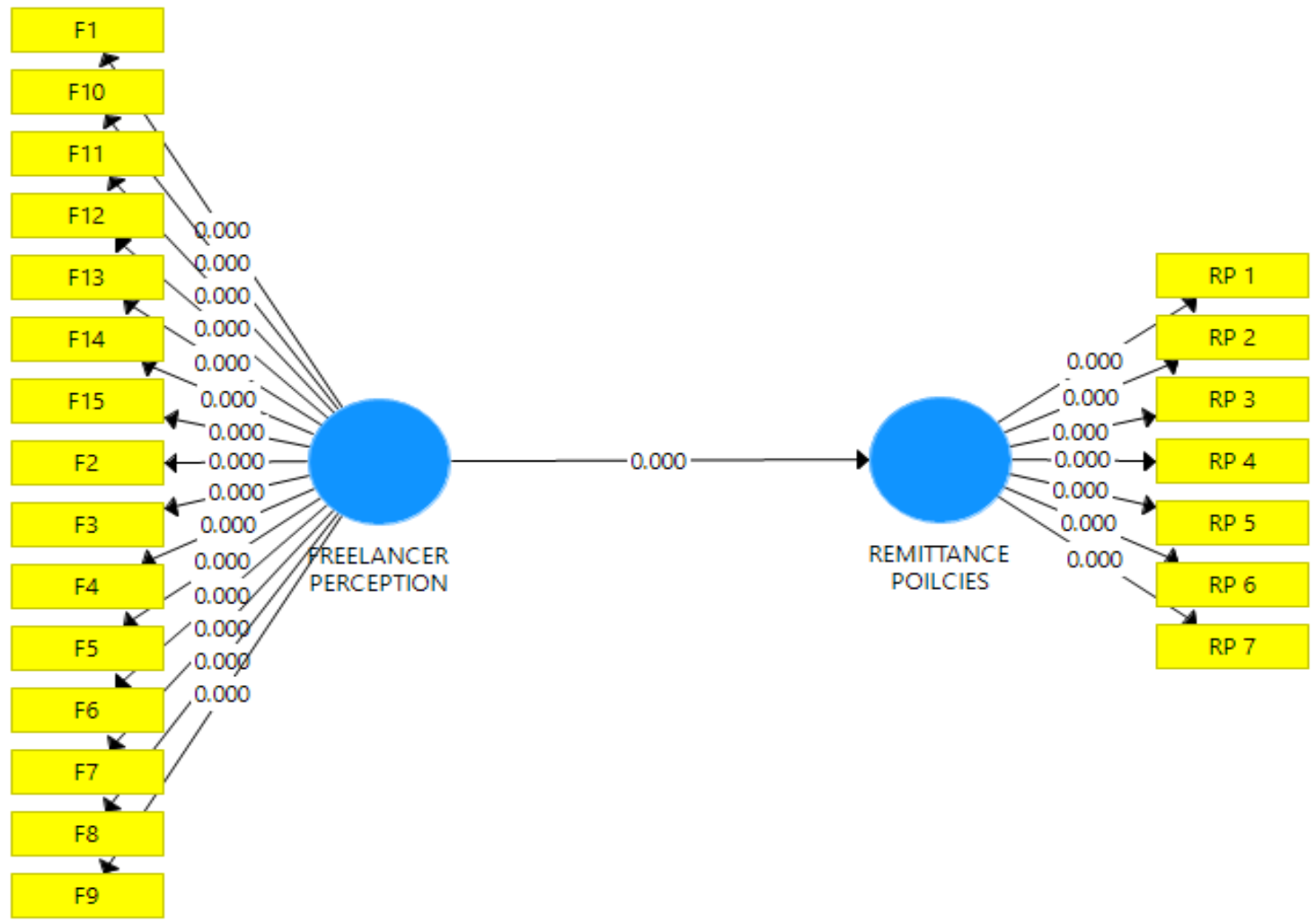

Figure-2. Research Model Diagram (Smart PLS)

In the package of Smart PLS, one of the key tools is bootstrapping which actually provides the stability and steadiness of the factor rough approximation information. Subtests are drawn for the primary model including substitution (Hair Jr, Matthews, Matthews, \& Sarstedt, 2017). As the above model is drawn in SmartPLS and several tests applied to check the hypothesis whether our hypothesis is acceptable or not. Further, the related questions annexed with variables

Table-9. Hypothesis Result derived from SmartPLS

\begin{tabular}{|c|c|c|c|c|c|}
\hline & $\begin{array}{c}\text { Original } \\
\text { Sample }(\mathbf{O})\end{array}$ & $\begin{array}{c}\text { Sample } \\
\text { Mean (M) }\end{array}$ & $\begin{array}{c}\text { Standard } \\
\text { Deviation } \\
\text { (STDEV) }\end{array}$ & $\begin{array}{c}\text { T Statistics } \\
(\mid \text { O/STDEV } \mid)\end{array}$ & $\begin{array}{c}\text { P } \\
\text { Valu } \\
\text { es }\end{array}$ \\
\hline $\begin{array}{l}\text { H } 1 \\
\text { Freelancer Perception } \quad-> \\
\text { Remittance Polices }\end{array}$ & 0.534 & 0.546 & 0.061 & 8.794 & 0.000 \\
\hline
\end{tabular}

As a result of the SmartPLS, the $\mathrm{H}_{1}$ is accepted because the p-value is acceptable which means that there is a positive and significant impact of freelancer's perception on remittance policies so, the null hypothesis is rejected. So, it can further conclude that in Pakistan government should take some important initiatives for freelancers. 
Table-10. Averages Outcome from SmartPlS

\begin{tabular}{|c|c|c|c|c|c|c|c|c|c|c|}
\hline Variables & Questions & No. & Missing & Mean & Median & Min & $\operatorname{Max}$ & $\begin{array}{l}\text { Standard } \\
\text { Deviation }\end{array}$ & $\begin{array}{l}\text { Excess } \\
\text { Kurtosis }\end{array}$ & Skewness \\
\hline \multirow{15}{*}{ 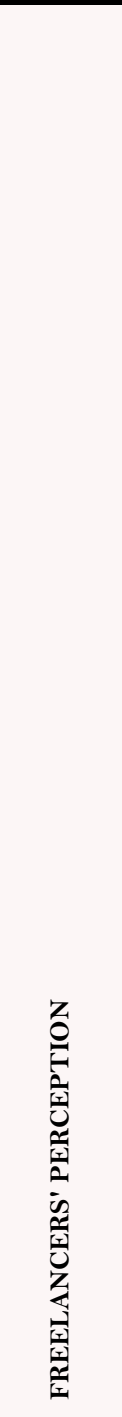 } & $\begin{array}{l}\text { I am often confused or } \\
\text { puzzled about what I am } \\
\text { feeling because of my job } \\
\text { nature }\end{array}$ & 1 & 0 & 2.24 & 2 & 1 & 3 & 0.615 & -0.567 & -0.201 \\
\hline & $\begin{array}{l}\text { I never know exactly } \\
\text { what kind of feeling I am } \\
\text { having while doing my } \\
\text { job }\end{array}$ & 2 & 0 & 2.304 & 2 & 1 & 3 & 0.574 & -0.585 & -0.13 \\
\hline & $\begin{array}{l}\text { Sometimes, I feel upset } \\
\text { and I have no idea why } \\
\text { because of my job }\end{array}$ & 3 & 0 & 2.397 & 2 & 1 & 3 & 0.598 & -0.662 & -0.429 \\
\hline & $\begin{array}{l}\text { I don't know when } \\
\text { something will upset me } \\
\text { or not }\end{array}$ & 4 & 0 & 2.358 & 2 & 1 & 3 & 0.537 & -0.887 & 0.014 \\
\hline & $\begin{array}{l}\text { I find it difficult to } \\
\text { explain to a friend how I } \\
\text { feel while doing my work }\end{array}$ & 5 & 0 & 2.368 & 2 & 1 & 3 & 0.592 & -0.675 & -0.332 \\
\hline & $\begin{array}{l}\text { I find it hard to talk to } \\
\text { anyone about how I feel } \\
\text { about my job }\end{array}$ & 6 & 0 & 2.338 & 2 & 1 & 3 & 0.584 & -0.655 & -0.237 \\
\hline & $\begin{array}{l}\text { I can easily explain to a } \\
\text { friend how I feel inside }\end{array}$ & 7 & 0 & 2.363 & 2 & 1 & 3 & 0.638 & -0.66 & -0.498 \\
\hline & $\begin{array}{l}\text { When I am upset about } \\
\text { something, I often keep } \\
\text { it to myself }\end{array}$ & 8 & 0 & 2.407 & 2 & 1 & 3 & 0.583 & -0.713 & -0.381 \\
\hline & $\begin{array}{l}\text { When I am upset, I try } \\
\text { not to show it }\end{array}$ & 9 & 0 & 2.333 & 2 & 1 & 3 & 0.631 & -0.671 & -0.41 \\
\hline & $\begin{array}{l}\text { When I am feeling bad, it } \\
\text { is no one else's business }\end{array}$ & 10 & 0 & 2.343 & 2 & 1 & 3 & 0.61 & -0.651 & -0.358 \\
\hline & $\begin{array}{l}\text { don't want to know how } \\
\text { my friends are feeling } \\
\text { about my job nature }\end{array}$ & 11 & 0 & 2.422 & 2 & 1 & 3 & 0.593 & -0.656 & -0.474 \\
\hline & $\begin{array}{l}\text { I don't care about how } \\
\text { my friends are feeling } \\
\text { inside because of my } \\
\text { nature of job }\end{array}$ & 12 & 0 & 2.353 & 2 & 1 & 3 & 0.613 & -0.653 & -0.388 \\
\hline & $\begin{array}{l}\text { It is important to } \\
\text { understand how I am } \\
\text { feeling }\end{array}$ & 13 & 0 & 2.377 & 2 & 1 & 3 & 0.602 & -0.659 & -0.4 \\
\hline & $\begin{array}{l}\text { I always want to know } \\
\text { why I feel bad about } \\
\text { something }\end{array}$ & 14 & 0 & 2.319 & 2 & 1 & 3 & 0.619 & -0.652 & -0.341 \\
\hline & $\begin{array}{l}\text { I always know how my } \\
\text { friends are feeling about } \\
\text { my work }\end{array}$ & 15 & 0 & 2.343 & 2 & 1 & 3 & 0.569 & -0.691 & -0.165 \\
\hline \multirow{7}{*}{ 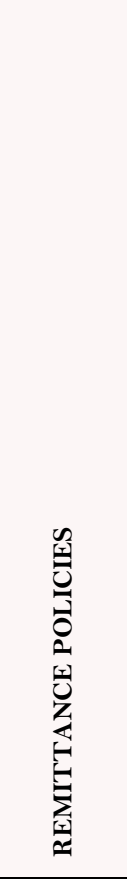 } & $\begin{array}{l}\text { The government does a } \\
\text { good job of providing } \\
\text { opportunities for } \\
\text { development and growth } \\
\text { for freelancers }\end{array}$ & 16 & 0 & 3.431 & 4 & 1 & 5 & 1.098 & -0.309 & -0.54 \\
\hline & $\begin{array}{l}\text { People have equal access } \\
\text { to job-related training } \\
\text { opportunities }\end{array}$ & 17 & 0 & 3.52 & 4 & 1 & 5 & 1.1 & -0.465 & -0.473 \\
\hline & $\begin{array}{l}\text { I have the opportunity to } \\
\text { work with up-to-date } \\
\text { technologies }\end{array}$ & 18 & 0 & 3.49 & 4 & 1 & 5 & 1.1 & -0.191 & -0.575 \\
\hline & $\begin{array}{l}\text { I have the opportunity to } \\
\text { learn skills that will } \\
\text { improve my chances for } \\
\text { growth }\end{array}$ & 19 & 0 & 3.716 & 4 & 1 & 5 & 1.079 & 0.224 & -0.828 \\
\hline & $\begin{array}{l}\text { There are government } \\
\text { concerns' to whom I can } \\
\text { go for help when I have } \\
\text { payment/remittance } \\
\text { related problems }\end{array}$ & 20 & 0 & 3.495 & 4 & 1 & 5 & 1.059 & 0.014 & -0.548 \\
\hline & $\begin{array}{l}\text { Government provides me } \\
\text { with the appropriate } \\
\text { amount of guidance } \\
\text { available when I need }\end{array}$ & 21 & 0 & 3.559 & 4 & 1 & 5 & 0.981 & 0.161 & -0.558 \\
\hline & $\begin{array}{l}\text { Government encourages } \\
\text { me to grow more } \\
\text { through relaxation in } \\
\text { policies. }\end{array}$ & 22 & 0 & 3.382 & 4 & 1 & 5 & 1.18 & -0.509 & -0.509 \\
\hline
\end{tabular}




\subsubsection{Results from SmartPLS}

A given table extracted from SmartPLS which is consist of the total questions asked from respondents, the column "missing" which shows all values are proper (as showing zero), minimum and maximum value of Likert scale further mean, median, standard deviation, kurtosis and skewness of all questions.

\subsection{Remittances impact on the Economy}

As the main indicators data extract from World Bank | Data Bank to analyze the results and to verify the hypothesis. So, the main data collected from there is consist of;

1. Unemployment Rate (2009 to 2019).

2. Personal Inward Remittances Amount (2009 to 2019).

3. Inflation Rate (2009 to 2019).

4. Reserves Amount (2009 to 2019).

\subsection{Economic Indicator - Inflation}

Table-11. Inflation Data Analysis

\begin{tabular}{|c|c|c|c|c|c|c|c|c|c|c|c|}
\hline Year & 2009 & 2010 & 2011 & 2012 & 2013 & 2014 & 2015 & 2016 & 2017 & 2018 & 2019 \\
\hline & $\%$ & $\%$ & $\%$ & $\%$ & $\%$ & $\%$ & $\%$ & $\%$ & $\%$ & $\%$ & $\%$ \\
\hline $\begin{array}{c}\text { Inflation, consumer } \\
\text { prices (annual \%) }\end{array}$ & 13.65 & 12.94 & 11.92 & 9.68 & 7.69 & 7.19 & 2.53 & 3.77 & 4.09 & 5.08 & 10.58 \\
\hline Change in Year & ------- & $(0.71)$ & $(1.02)$ & (2.23) & (1.99) & $(0.50)$ & $(4.66)$ & 1.24 & 0.32 & 0.99 & 5.50 \\
\hline
\end{tabular}

As in the year 2009, the rate of inflation was 13.65 which is much higher than the year 2019. It is not just because of the remittances but due to the other factors because it is showing the overall impact of the economy. In the year 2019 the rate of inflation is 10.58 which is higher as compared to the year 2015. A lot of contribution from the year 2015 to 2017 recorded (PSEB-Pakistan Software Export Board).

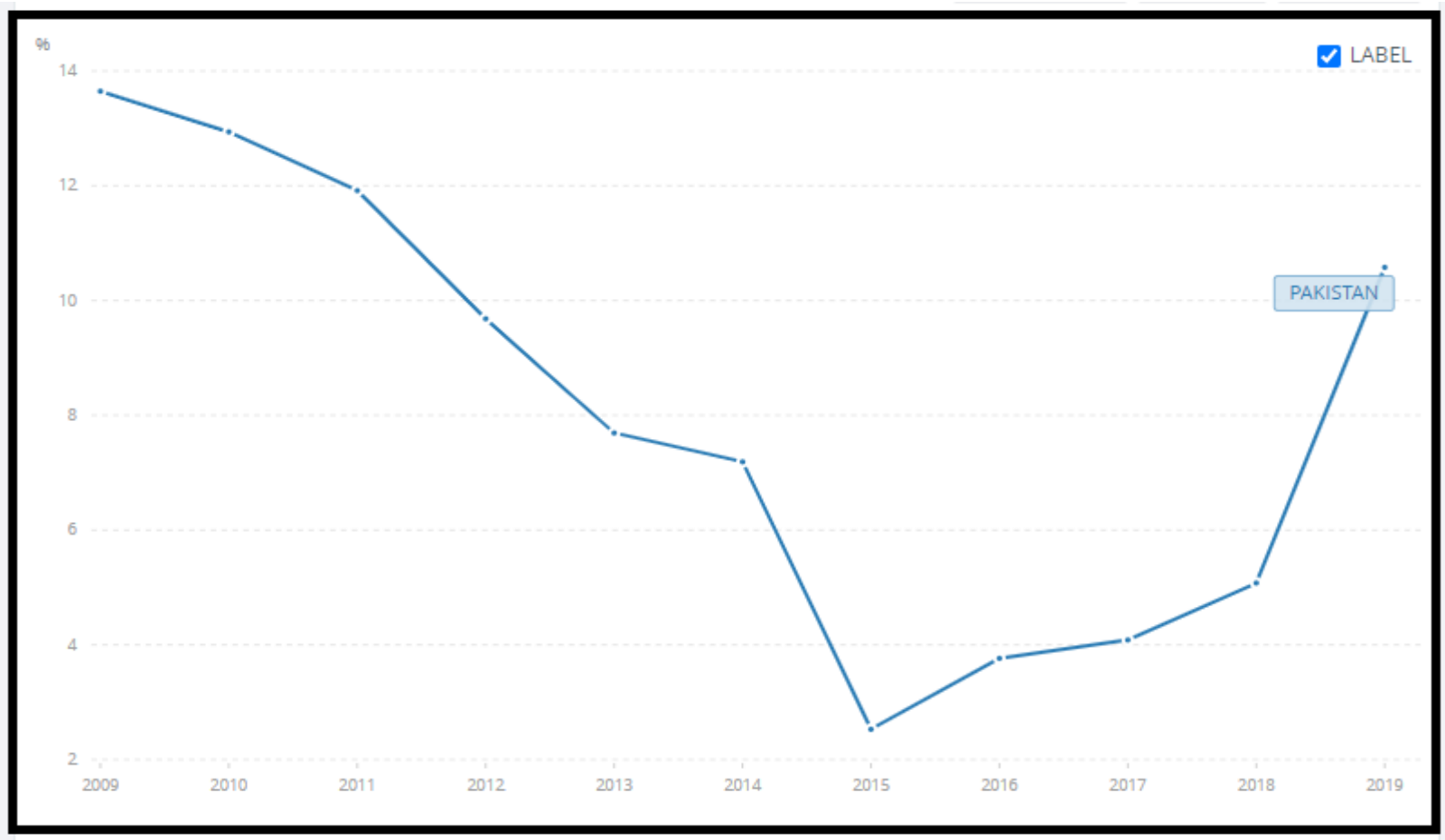

Figure-3. Inflation Behavior from 2009-2019 
Table-12. Remittances data Analysis

\begin{tabular}{|c|c|c|c|c|c|c|c|c|c|c|c|}
\hline Year & 2009 & 2010 & 2011 & 2012 & 2013 & 2014 & 2015 & 2016 & 2017 & 2018 & 2019 \\
\hline Amount in ' $\mathrm{O}$ ' & 00,000 & 00,000 & 00,000 & 00,000 & 00,000 & 00,000 & 00,000 & 00,000 & 00,000 & 00,000 & 00,000 \\
\hline Amount & 87,170 & 96,900 & 122,630 & 140,070 & 146,290 & 172,440 & 193,060 & 198,190 & 198,560 & 211,930 & 222,450 \\
\hline Change in Amount & - & 09,730 & 25,730 & 17,440 & 06,220 & 26,150 & 20,620 & 05,130 & 00,370 & 13,370 & 10,520 \\
\hline Percentage Change & - & $11.16 \%$ & $26.55 \%$ & $14.22 \%$ & $4.44 \%$ & $17.88 \%$ & $11.96 \%$ & $2.66 \%$ & $0.19 \%$ & $6.73 \%$ & $4.96 \%$ \\
\hline
\end{tabular}

As in the year 2009, the remittances amount received Rs. 87,170 (hundred thousands) which is much lower than $2013-2014$ because at that time people of the country don't aware about the field of information technology and it can clearly see that in 2014 a drastic move upward recorded because of people of Pakistan showing interest in the field of information technology (I.T) as freelancer. Now, in 2019, the figure is 222,450 which is $40 \%$ higher than 2009 as the behavior of the change and its variation can be clearly seen in the given table.

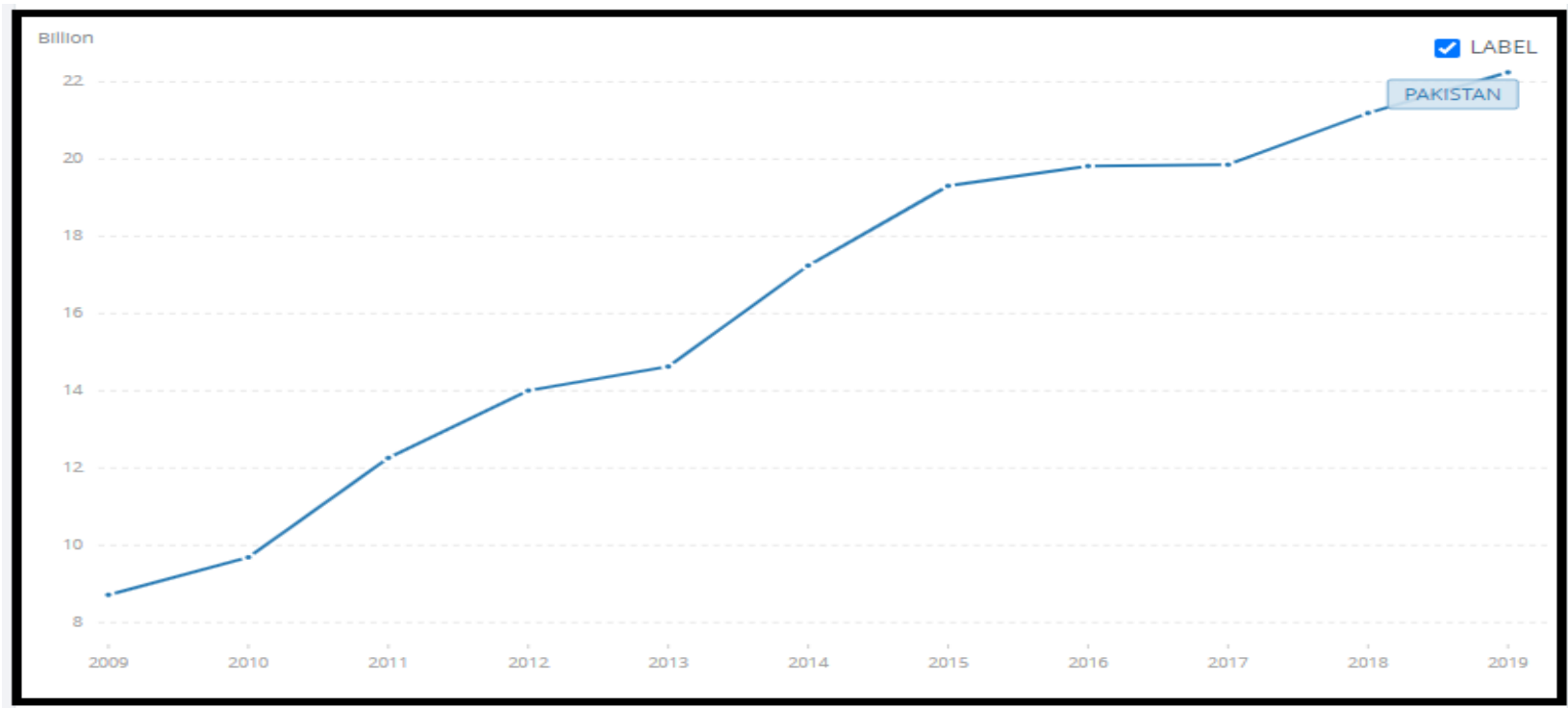

Figure-4. Remittances Behavior from 2009-2019

8.6. Economic Indicator - Unemployment

Table-13. Unemployment Data Analysis

\begin{tabular}{c|c|c|c|c|c|c|c|c|c|c|c}
\hline Year & $\mathbf{2 0 0 9}$ & $\mathbf{2 0 1 0}$ & $\mathbf{2 0 1 1}$ & $\mathbf{2 0 1 2}$ & $\mathbf{2 0 1 3}$ & $\mathbf{2 0 1 4}$ & $\mathbf{2 0 1 5}$ & $\mathbf{2 0 1 6}$ & $\mathbf{2 0 1 7}$ & $\mathbf{2 0 1 8}$ & $\mathbf{2 0 1 9}$ \\
\hline & $\mathbf{\%}$ & $\mathbf{\%}$ & $\mathbf{\%}$ & $\mathbf{\%}$ & $\mathbf{\%}$ & $\mathbf{\%}$ & $\mathbf{\%}$ & $\mathbf{\%}$ & $\boldsymbol{\%}$ & $\mathbf{\%}$ & $\mathbf{\%}$ \\
\hline Inflation & 1.10 & 1.31 & 1.74 & 3.52 & 6.05 & 4.10 & 6.73 & 7.22 & 7.60 & 7.98 & 8.88 \\
\hline Change & & 0.21 & 0.44 & 1.78 & 2.53 & $(1.95)$ & 2.63 & 0.49 & 0.38 & 0.38 & 0.90 \\
\hline
\end{tabular}

As data are taken from the World Bank, the unemployment rate of Pakistan is continuously rising. From the year 2009 to 2013, a drastic move towards downward can be seen easily and in 2014 it was declined due to some government reforms and policies. Record unemployment is recorded in 2019 with a pace of 0.9 but it can be controlled through policies in the field of inward remittances and must provide some leverage to freelances because, in this way, a new industry can be developed. The variation and change can be seen in the given table extracted from the World Bank data. 


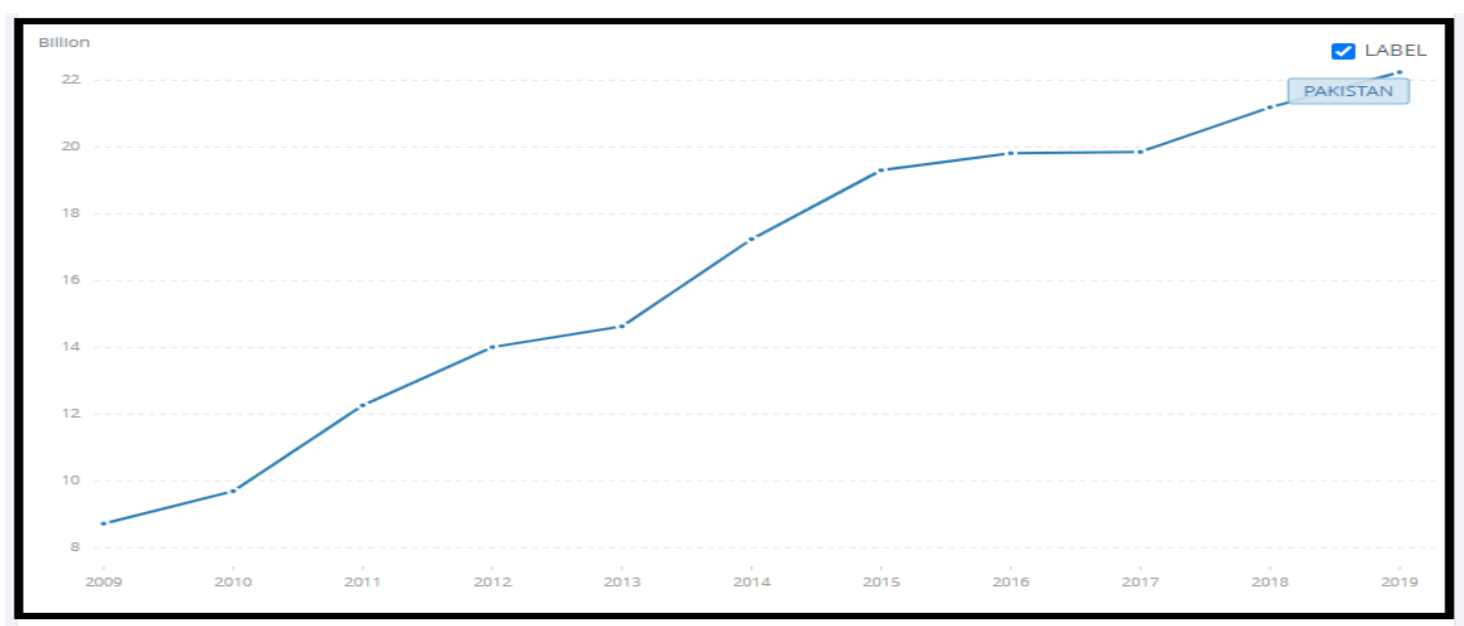

Figure-5. Unemployment Behavior from 2009-2019

(Table Extracted from Source: The World Bank | Data).

8.7. Economic Indicator - Reserves

Table-14. Reserves Data Analysis

\begin{tabular}{|c|c|c|c|c|c|c|c|c|c|c|c|}
\hline Year & 2009 & 2010 & 2011 & 2012 & 2013 & 2014 & 2015 & 2016 & 2017 & 2018 & 2019 \\
\hline $\begin{array}{c}\text { Amount in } \\
\text { 'O' }\end{array}$ & 00,000 & 00,000 & 00,000 & 00,000 & 00,000 & 00,000 & 00,000 & 00,000 & 00,000 & 00,000 & 00,000 \\
\hline Amount & 136,061 & 172,555 & 17,697 & 136,884 & 76,512 & 143,068 & 200,278 & 22,0276 & 184,558 & 118,371 & 165,860 \\
\hline $\begin{array}{c}\text { Change in } \\
\text { Amount }\end{array}$ & - & 36,494 & 4,423 & $(40,094)$ & $(60,372)$ & 66,555 & 57,210 & 19,997 & $(35,717)$ & $(66,186)$ & 47,488 \\
\hline $\begin{array}{c}\text { Increase } \\
\text { OR } \\
\text { Decrease }\end{array}$ & & $21.15 \%$ & $2.50 \%$ & $-29.29 \%$ & $-78.90 \%$ & $46.52 \%$ & $28.57 \%$ & $9.08 \%$ & $-19.35 \%$ & $-55.91 \%$ & $28.63 \%$ \\
\hline
\end{tabular}

The reserves have a significant change over years. In the year $2012-2013$, reserves $29 \%-78 \%$ decreases which were a very disturbing situation of Pakistan, and at that time political instability was also observed. In the year 2014 to 2016, an exceptional boom in reserves cause political stability and growth of small businesses and an exceptional export of software's (services) as per the report of PSEB (PSEB - Google Search, 2018-2021) But in 2017 to 2018 a significant decrease in reserves due to unstable policies, government and political instability directly impact the reserves and eventually, it has a direct impact on exchange rate. Freelancers can impact the economy as well by an increase in the export of software as seen in $2014-2015$.

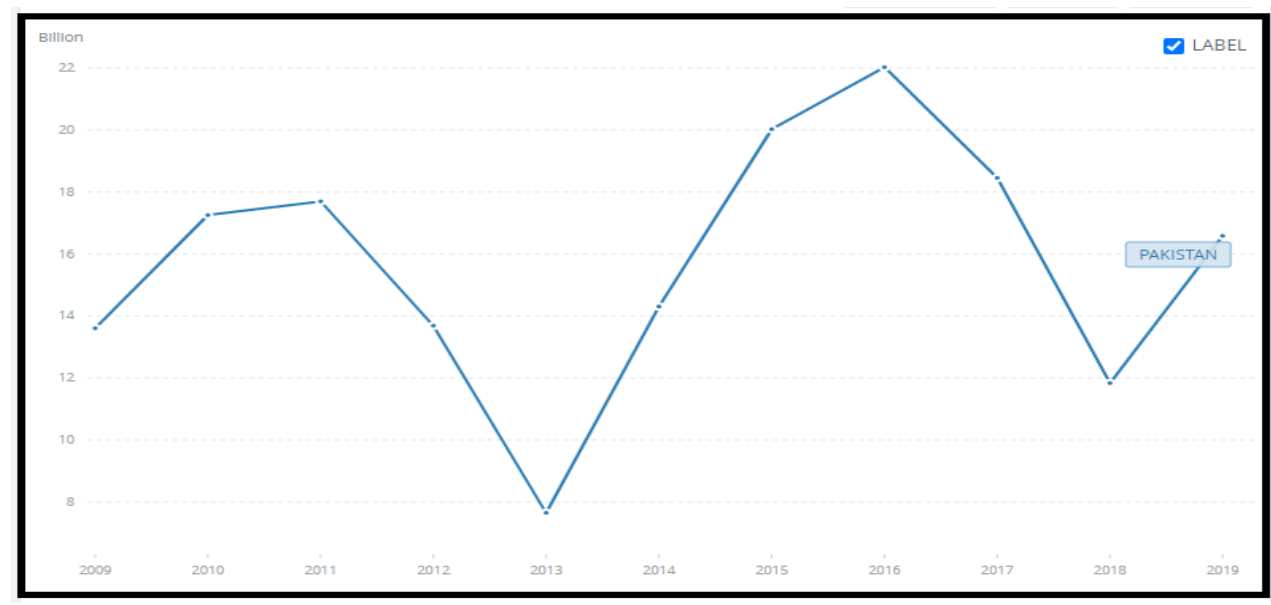

Figure-6. Reserves Behavior from 2009-2019. 


\section{DISCUSSION AND CONCLUSION}

Table-15. Hypothesis Conclusion Table

\begin{tabular}{c|l|c}
\hline $\mathbf{H}(\mathbf{x})$ & Hypothesis & Findings \\
\hline H 1 & $\begin{array}{l}\text { There is a positive and a significant impact of freelancer perception on inward } \\
\text { remittance policies. }\end{array}$ & Supported \\
\hline H 2 & $\begin{array}{l}\text { There is a positive and a significant impact of Inward remittance on the } \\
\text { economy of the country }\end{array}$ & Supported \\
\hline
\end{tabular}

The study examined the impact of freelancer perception on remittances policies that are currently applicable in Pakistan and assess the impact on the economy of the country. As an application of different test over respondent responses, the impact found positive as the hypothesis has accepted significantly because as per the report of PESB (Pakistan Export Software Board) during 2015-2016 the overall export and proceed against services (I.T) was about 2,8 billion and the same has a significant impact on balance on payment, inflation, and reserves. After critical evaluation of data which were extracted from the World Bank, it was seen significant variation;

\begin{tabular}{|c|c|c|}
\hline Remittance & 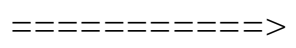 & Upward \\
\hline Reserves & $=========>$ & Upward \\
\hline Inflation & $==========>$ & Downward \\
\hline
\end{tabular}

So, based on facts, the model hypothesis has accepted because $\mathrm{H} 1$ accepted based on outcome provided by SmartPLS and as per evaluation on data the same result also was seen after application of systematic tools (analysis and graph) $\mathrm{H} 2$ also accepted.

\section{IMPLEMENTATION OF THE STUDY}

It is important to understand how this study can be helpful for the country to improve its economy. As the analysis above, the survey was conducted among individuals instead of corporates or businesses and found a significant impact on the overall economy. World Bank argued that the remittances impact positively on the balance of payment in most of the developing countries as well as the enhancement in the economy via rising in savings and investment and have an indirect impact through consumption (Ratha, 2005). A remittance indicator is a tool for decision making because it has a direct impact on inflation, unemployment, and reserves so, the I.T field should be necessary to everyone because it can create opportunities and decrease the poverty rate as well. It is adequately the role that is currently playing the internet is building international support (Carter, Clegg, Hogan, \& Kornberger, 2003).

\section{LIMITATION AND FUTURE RECOMMENDATION}

The study conducted within the specific area of the Pakistan region i.e. Karachi North and the results based on that locality. It was a satisfactory response from respondents because before it no study was conducted in this area. So, it can be conducted within the other regions of Pakistan and results may vary as per respondent's attitude. It is also recommended to conduct the research on other provinces of Pakistan and within the academic institution as per assumptions that either youth is interested to pursue a career in the field of I.T as a freelancer. Further, it is another dimension that can be analyzed through critical evaluation of exchange rates for reserves and how can achieve an overall positive outcome through I.T (Freelancer).

Funding: This study received no specific financial support.

Competing Interests: The authors declare that they have no competing interests.

Acknowledgement: Both authors contributed equally to the conception and design of the study. 


\section{REFERENCES}

Abel, A. B. (1970). 5. Suppose inflation adjustment is given by (11.22). The central bank's objective is to minimize. Journal of Economics, 84(3), 488-500.

Armstrong, N. A., Crossfield, A. S., Kincheloe, I. C., McKay, J. B., Walker, J. A., White, A. S., \& White, R. M. (1971). From Wikipedia, the free encyclopedia. Age.

Barlage, M., van den Born, A., \& van Witteloostuijn, A. (2019). The needs of freelancers and the characteristics of 'gigs': Creating beneficial relations between freelancers and their hiring organizations. Emerald Open Research, 1, 8.

Bido, D. D. S., Silva, D. d., \& Ringle, C. M. (2014). Structural equation modeling with the SmartPLS. Brazilian Marketing Magazine, 13(2), 56-73.

Carter, C., Clegg, S., Hogan, J., \& Kornberger, M. (2003). The polyphonic spree: The case of the Liverpool Dockers. Industrial Relations Journal, 34(4), 290-304.Available at: https://doi.org/10.1111/1468-2338.00276.

Chawathe, S., Garcia-Molina, H., Hammer, J., Ireland, K., Papakonstantinou, Y., Ullman, J., \& Widom, J. (1994). The TSIMMIS project: Integration of heterogenous information sources.

Cox, J. E. (1972). Western union digital services. Proceedings of the IEEE, 60(11), 1350-1357.Available at: https://doi.org/10.1109/proc.1972.8903.

George, D., \& Mallery, P. (2003). SPSS for Windows, step by step: A simple guide and reference (14th ed., pp. 222-232). Boston: Allyn \& Bacon.

Godelnik, R. (2017). Millennials and the sharing economy: Lessons from a 'buy nothing new, share everything month'project. Environmental Innovation and Societal Transitions, 23, 40-52.Available at: https://doi.org/10.1016/j.eist.2017.02.002.

Greene, A. m., \& Kirton, G. (2003). Possibilities for remote participation in trade unions: Mobilising women activists. Industrial Relations Journal, 34(4), 319-333.Available at: https://doi.org/10.1111/1468-2338.00278.

Hair Jr, J. F., Matthews, L. M., Matthews, R. L., \& Sarstedt, M. (2017). PLS-SEM or CB-SEM: Updated guidelines on which method to use. International Journal of Multivariate Data Analysis, 1(2), 107-123.Available at: https://doi.org/10.1504/ijmda.2017.087624.

Income. (202 1). In Wikipedia. Retrieved from https://en.wikipedia.org/w/index.php?title=Income\&oldid=998478699.

Kalleberg, A. L., \& Dunn, M. (2016). Good jobs, bad jobs in the gig economy. LERA for Libraries, 20(1-2).

Kozierok, C. (2011). Online freelancing guide, 2011. Retrieved from Http://Www.Freelancingguide.Net/Index.Htm.

Kulkarni, S. P., \& Ramamoorthy, N. (2005). Commitment, flexibility and the choice of employment contracts. Human Relations, 58(6), 741-761.Available at: https://doi.org/10.1177/0018726705057170.

Lehdonvirta, V. (2018). Flexibility in the gig economy: Managing time on three online piecework platforms. New Technology, Work and Employment, 33(1), 13-29.Available at: https://doi.org/10.1111/ntwe.12102.

Meyer, D., \& Shera, A. (2017). The impact of remittances on economic growth: An econometric model. EconomiA, 18(2), 147155.Available at: https://doi.org/10.1016/j.econ.2016.06.001.

Nemkova, E., Demirel, P., \& Baines, L. (2019). In search of meaningful work on digital freelancing platforms: The case of design professionals. New Technology, Work and Employment, 34(3), 226-243.Available at: https://doi.org/10.1111/ntwe.12148.

Pongratz, H. J. (2018). Of crowds and talents: Discursive constructions of global online labour. New Technology, Work and Employment, 33(1), 58-73.Available at: https://doi.org/10.1111/ntwe.12104.

PSEB - Google Search. (2018-2021). Retrieved from: https://www.pseb.org.pk/.

Ratha, D. (2005). Workers' remittances: An important and stable source of external development finance. 19-51.

RESERVE | Meaning in the Cambridge English Dictionary. (2020). Retrieved from https://dictionary.cambridge.org/dictionary/english/reserve. [Accessed January 22, 202 1].

Rieffe, C., Oosterveld, P., \& Terwogt, M. M. (2006). An alexithymia questionnaire for children: Factorial and concurrent validation results. Personality and Individual Differences, 40(1), 123-133.Available at: https://doi.org/10.1016/j.paid.2005.05.013. 
Saundry, R., Stuart, M., \& Antcliff, V. (2007). Broadcasting discontent-freelancers, trade unions and the Internet. New Technology, Work and Employment, 22(2), 178-191.

Spencer, D. (2017). Work in and beyond the Second Machine Age: the politics of production and digital technologies. Work, employment and society, 31(1), 142-152.

Spencer., D. A. (2015). Developing an understanding of meaningful work in economics: The case for a heterodox economics of work. Cambridge Journal of Economics, 39(3), 675-688.Available at: https://doi.org/10.1093/cje/beu074.

State Bank of Pakistan-Google Search. (2020). Retrieved from: https://www.sbp.org.pk/.

State Bank of Pakistan Balance of Payment. (2020). Retrieved from: https://www.sbp.org.pk/.

Storey, J., Salaman, G., \& Platman, K. (2005). Living with enterprise in an enterprise economy: Freelance and contract worker s in the media. Human Relations, 58(8), 1033-1054.

Süß, S., \& Kleiner, M. (2010). Commitment and work-related expectations in flexible employment forms: An empirical study of German IT freelancers. European Management Journal, 28(1), 40-54.Available at: https://doi.org/10.1016/j.emj.2009.02.002.

Wan, H. L. (2007). Human capital development policies: Enhancing employees' satisfaction. Journal of European Industrial Training, 31(4), 297-322.

Zuckerman, E. W., Kim, T.-Y., Ukanwa, K., \& Von Rittmann, J. (2003). Robust identities or nonentities? Typecasting in the feature-film labor market. American Journal of Sociology, 108(5), 1018-1074.Available at: https://doi.org/10.1086/377518.

Views and opinions expressed in this article are the views and opinions of the author(s), International Journal of Publication and Social Studies shall not be responsible or answerable for any loss, damage or liability etc. caused in relation to/arising out of the use of the content. 